Милош Ковић

Универзитет у Београду

Филозофски факултет

Одељење за историју

mkovic@f.bg.ac.rs
Оригинални научни рад

примљено: 30. мај 2011

прихваћено: 1. октобар 2011

\title{
„ЦИВИЛИЗАТОРСКА МИСИЈА“ АУСТРОУГАРСКЕ НА БАЛКАНУ: ПОГЛЕД ИЗ БЕОГРАДА (1901-1914)
}

Сажетак: У чланку се сукоб Србије са Аустроугарском у годинама уочи Првог светског рата сагледава у ширем, светском контексту «доба империја». Балкан је за Аустроугарску био оно што су за остале колонијалне силе тога доба биле Африка или Азија. Као идеолошко образложење империјалних похода Двојне монархије коришћена је, најчешће, њена „цивилизаторска мисија“ на „полудивљем“ Балкану. У овом чланку показано је да су водећи српски интелектуалци овог доба, који су се окупљали око Српског књижевног гласника, били свесни колонијалне суштине и «цивилизаторских» амбиција Хабзбуршке политике на Балкану. Своје јавно деловање, укључујући и научну и уметничку продукцију, они су прилагођавали потреби отпора «културној мисији» суседне империје.

Кључне речи: империјализам, колонијализам, „цивилизаторска мисија“, национализам, Аустроугарска, Србија, Српски къижевни гласник.

I

Пјер Ренувен је давно приметио да историја Србије у деценији уочи Првог светског рата не може да се разуме ван контекста њеног сукоба са Аустроугарском. ${ }^{1}$ Штавише, Ренувенову опаску могли бисмо да проширимо у тврдњу да се политичка, економска, па ни културна историја српског народа у добу између уласка трупа Аустроугарске у Босну и Херцеговину 1878. и Сарајевског атентата 1914. не може разумети ван оквира оцртаних отпором српског национализма пред Хабзбуршким империјализмом. Овај отпор зачео се у српском друштву, у масовном одзиву гласача на поруке Народне радикалне странке, да би се сасвим уобличио 1895, окретањем чак и Српске напредне странке Русији. ${ }^{2}$ После нестанка Обреновића са историјске сцене 1903. друштво је „освојило“ државу, па је отпор српског друштва

\footnotetext{
${ }^{1}$ Pierre Renouvin, Evropska kriza i Prvi svjetski rat, Zagreb 1965, 99.

${ }^{2}$ Вид. Михаило Војводић, Србија у међународним односима крајем ХІХ и почетком ХХ века, Београд 1988, 43-56.
} 
пред империјалним амбицијама суседне царевине узео облик сукоба између две државе.

Овим чланком покушаћемо да подсетимо на шири, европски и светски контекст овог сукоба. Светска збивања у овом добу била су, пре свега, одређена феноменом империјализма - борбом великих сила за стварање колонијалних царстава. Ерик Хобсбаум, у својој славној трилогији посвећеној 19. веку, није случајно цео период од 1875. до 1914. назвао «доба империја». ${ }^{3}$ Студије империја и империјализма данас се сматрају посебно важном, актуелном темом и литература о овим феноменима непрекидно расте. ${ }^{4}$

Поробљавање „малих“, далеких земаља и народа није било нешто ново у светској историји. Ипак, у „добу империја“ процес европских освајања и колонизације удаљених континената нагло се убрзао, да би, у овој првој ери глобализације, до 1914, скоро цео свет био подељен између великих сила. Нова су била и теоријска, идеолошка образложења, коришћена за оправдавање ових освајачких подухвата. Економска оправдања позивала су се на потрагу за новим тржиштима, изворима сировина и јефтине радне снаге. Расистичке теорије, намењене поробљавању Африке и, у мањој мери, Азије, позивале су се на нужност да „више“, „чисте“ расе владају „нижим“, „мешаним“ расама. Социјалдарвинисти су тврдили да би, баш као у природи, слаби и неприлагодљиви требало да подлегну у борби за опстанак, на корист великих, јаких и прилагодљивих друштава и држава. Коначно, било је много оних који су веровали да је дужност Европљана била да помогну „примитивним“ народима да усвоје благодети цивилизације. Тврдили су да су локални, племенски ратови могли да буду заустављени само страном окупацијом. Европска администрација требало је да заведе мир, поправи исхрану, услове становања, здравство, комуникације. Затим би локално становништво могло да ужива у благодетима хришћанства, западњачке науке и уметности. Ова доктрина називана је „цивилизаторском мисијом“ (la mission civilisatrice). Понекад се називала и „теретом белог човека“ по популарној песми Радјарда Киплинга (The White Man's Burden), из 1899, у којој се проповедала „дужност“ белог човека да „помогне“ осталим расама да се успну стазама „цивилизације“. У Бечу су, уместо ових израза, чешће користили синтагму „културна мисија“. Коначно, новија литература, нарочито у оквиру постколонијалних студија, трага за теоријским образложењима и изворима империјализма и колонијализма у уметности и науци. Ту се посебан нагласак ставља на теорије моћи и потребу колонизатора да владају душама, имовином и природним ресурсима других људи. ${ }^{5}$

\footnotetext{
${ }^{3}$ Eric Hobsbawm, The Age of Empire 1875-1914, London 1987.

${ }^{4}$ Корисни општи прегледи су: Encyclopedia of the Age of Imperialism, 1800-1914, I-II (ed. by Carl Cavanagh Hodge), Westport - London 2008; Encyclopedia of Western Colonialism since 1450, I-III (ed. by Thomas Benjamin), Detroit - New York 2007; Andrew Porter, European Imperialism 1860-1914, Houndmills -London 1994; Wolfgang J. Momsen, Theories of Imperialism, Chicago 1982.

5 За општи увод вид. Robert J. C. Young, Postcolonialism: A Very Short Introduction, Oxford - New York 2003; John Tomlinson, Cultural Imperialism: A Critical Introduction, London - New York 2002. У оквиру постколонијалних студија и изучавања «културног империјализма», за нашу тему посебан значај имају књиге: Edvard Said, Orijentalizam, Beograd 2008; Marija Todorova, Imaginarni Balkan, Beograd 2006.
} 
Примена ових теорија на политику Аустроугарске на Балкану, пре свега на њену управу над Босном и Херцеговином и деловима Новопазарског санџака 18781914. значила би да је за Беч владавина над овим земљама била оно што је за Лондон била владавина над Египтом или Индијом, а за Париз над Индокином или Алжиром. Извори, заиста, потврђују да се на балканску политику Хабзбуршке монархије гледало као на „цивилизаторску мисију“. Балканске земље налазе се, истина, у Европи и насељене су белим становништвом, али су сматране варварским и полуоријенталним, при чему се наглашавало да су биле хронично раздиране сукобима и уназађене примитивном привредом. У делу савремене стручне литературе се на политику Двојне монархије на Балкану, нарочито на њену управу над Босном и Херцеговином, гледа позитивно, као на велики модернизацијски подухват, што је само друго име за „цивилизаторску мисију“. Има, ипак, и историчара који владавину Аустроугарске над Босном и Херцеговином сматрају типичном за „доба империја“, при чему, да би је описали, користе и изразе „цивилизаторска мисија“ и „терет белог човека“. ${ }^{6}$

До сада, међутим, није истражено да ли су тадашње локалне, балканске елите у напредовању Аустроугарске на Балкану виделе „цивилизаторску мисију“, и да ли су је сагледавале у оквирима светских трендова из „доба империја“. Покушаћемо да истражимо ова питања на примеру групе водећих српских интелектуалаца, која се од 1901. до 1914. окупљала око најзначајнијег српског часописа, београдског Српског књижевног гласника. ${ }^{7}$ Реч је о интелектуалцима који ће, како је писао један од њих, Милан Грол, после 1903. „доћи на власт“, 8 и чије ће се идеје у потоњем добу претворити у званични културни модел Краљевине Србије.

\section{II}

Током осамдесетих и деведесетих година 19. века, сазревајући у Србији, угроженој, у тек стеченој независности, амбицијама суседне царевине, и школујући се у метрополама колонијалних царстава, генерације које ће се окупити у Српском

\footnotetext{
${ }^{6}$ За неслагања историчара о природи управе Аустроугарске у Босни и Херцеговини, уз закључак да је у питању класичан пример империјализма, вид. Alan Sked, The Decline and Fall of the Habsburg Empire 1815-1918, London - New York 1989, 243-246. Вид. нарочито: Robin Okey, Taming Balkan Nationalism: The Habsburg 'Civilizing Mission' in Bosnia, 1878-1914, Oxford 2007, vii-ix, 217-223, 251-257. Да је Босна и Херцеговина за Аустроугарску била «терет белог човека», као што је то за друге империје била Африка, тврди и Ален Џ. П. Тејлор, Хабсбуршка монархија 1809-1918. Историја Аустријске иаревине и Аустроугарске, Београд 2001, 173. „Цивилизаторска мисија“ у схватањима некрунисаног владара Босне и Херцеговине Бењамина Калаја посебно се истиче у: Tomislav Kraljačić, Kalajev režim u Bosni i Hercegovini 1882-1903, Sarajevo 1987, 61-87.

7 Литература о „старој серији“ Српског књижевног гласника је обимна и не може се обухватити једном напоменом. Међу новијим радовима свакако вид.: Драгиша Витошевић, Српски книжевни гласник 19011914, Београд 1990; Сто година Српског књижевног гласника, Аксиолошки аспект традиције у српској књижевној периодици (ур. Станиша Тутњевић и Марко Недић, Матица српска и Институт за проучавање књижевности и уметности, Београд 2003. Вид. и Љубица Ђорђевић, Библиографија Српског књижевног гласника, Београд 1982.

${ }^{8}$ Милан Грол, Богдан Поповић, Из предратне Србије: Утисци и сећања о времену и људима, Београд 1939, 59.
} 
књижевном гласнику упознале су империјализам из непосредног искуства. Тумачења и објашњења овог феномена проналазили су, опет, у књигама западноевропских писаца.

Јован Скерлић се већ у време студија у Лозани сусрео са теоријским образложењима империјализма и „цивилизаторске мисије“. У књизи Политички $u$ социјални проблеми крајем ХІХ века француског историчара Едуара Дриоа, Скерлић je пронашао тврдњу да је империјализам био најважнија политичка појава у тадашњој Европи. У приказу те књиге, који је из Лозане, 1900. године, послао београдској Звезди, ${ }^{9}$ Скерлић је препричавао Дриоове идеје, додајући им повремено и своја тумачења. Он пише: “Најкарактеристичнији појав при крају XIX века то је колонијално ширење”. 10 “Никада на кугли земљиној сила није била бруталнија, слаби бесправнији, а велики злочини прикривани крупнијим речима" - примећује, са Дриоом, Јован Скерлић. ${ }^{11}$ Он уочава и да се у Европи све учесталије помиње “цивилизаторска мисија“. Разлози "маније за колонизацијом” јесу економске природе, али “капиталистичка класа" је својим “полугусарским жељама и тежњама ударила маску интереса цивилизације и хришћанства“. ${ }^{12}$ У колонијалним освајањима предњаче западне силе, Енглеска и Француска; чак и Америка “која је за читавих сто година тако часно, и својом историјом, и својом политиком, заступала ствар националне слободе, и она се отровала империјализмом, и са Кубе скочила на Филипине". 13 Русија се бави “глођањем Кине са севера", Немачка и Италија продиру у Африку и “бацају се” на већ “полумртву Кину”. 14

Посебно важно било је то што је Скерлић код Дриоа пронашао следећу тврдњу: “Аустрија је једина од великих сила која нема колонија, али то само привидно. Дрио тврди да је Балканско полуострво у плану да постане аустријска колонија и пут којим ће Немачка продирати за Малу Азију”. ${ }^{15}$ Скерлић је, дакле, код француских писаца проналазио не само тумачење “цивилизаторске мисије” као изговора за империјалистичка освајања, него и тврдње да је за Хабзбуршку монархију Балкан био оно што су за остале силе биле Африка и Кина.

По Скерлићевом повратку са студија у иностранству, исти мотиви јављају се и у његовим текстовима у Српском књижевном гласнику. Његови чланци у овом часопису већ тада су били веома запажени. Када буде преузео уредништво од Богдана Поповића, прво заједно са Павлом Поповићем (1905-1907), а затим сасвим сам (1907-1914), он ће давати тон целом Гласнику.

\footnotetext{
${ }^{9}$ Јован Скерлић, Политички и соиијални проблеми крајем XIX века, Les problemes politiques et sociaux á la fin du XIX-e siècle, par E. Driault, professeur agrégé d'histoire au lycée d’Orléans, Фељтони, скице и говори, Сабрана дела Јована Скерлића VII, Београд 1964, 49-52.

${ }^{10}$ Исто, 49.

${ }^{11}$ Исто, 50.

12 Исто, 49.

${ }^{13}$ Исто, 50.

${ }^{14}$ Исто.

${ }^{15}$ Исто. 
У чланку Омладински конгреси из 1904, Скерлић је балканске народе упозоравао на опасност од “полу-феудалне и клерикалне Аустрије”, ${ }^{16}$ и тврдио да ће они или сарађивати, или ће им преостати само да очекују “дан када ће се постати или руска губернија или аустријска провинција”. ${ }^{17}$ Пошто је одбацио средњоевропске и источноевропске утицаје, Скерлић је закључио “да је Запад извор светлости и жижа живота на земљи; да за нове народе има два пута, или примити западну културу, као Јапанци, и живети, или јој стати на супрот, и бити прегажен, као амерички Црвенокошци или аустралијски Црнци...”18

Помињање Јапанаца, црвенокожаца и црнаца показује да је Јован Скерлић размишљао о глобалним феноменима, и да је искуство Срба са суседном царевином стављао у тај контекст. У тексту Начело солидарности он ће чак Србију назвати "Кином на Балкану". ${ }^{19}$ Свест о значају културне припадности за будућност "малих" и "нових" народа, донела је уверење да је примање “западне културе” основни услов опстанка. При томе, требало је одбацити наметљиве, колонијалне, средњоевропске културне моделе и усвојити западњачке, француске, британске, па и америчке културне обрасце. У тим идејама требало би тражити суштину идеологије Српског књижевног гласника.

По мишљењу Гласникових уредника и сарадника, иза “цивилизацијске" реторике Беча стајале су империјалне, освајачке амбиције немачких елита; иза њих наслућивала се много већа, пангерманска опасност. Цивилизаторске амбиције суседне империје биле су један од главних узрока Гласникове изразито “западњачке" идеологије. Доказивањем свог западњачког идентитета, и “способности за културу”, како се тада говорило, требало је Аустроугарској одузети њене „цивилизаторске“ аргументе и сачувати самосталност; у исто време, тиме је требало стећи подршку Запада за остваривање сопствених националних циљева.

Да је Јован Скерлић јасно уочавао основне одлике доба империја види се и из његових текстова написаних пред крај живота. У чланку Нови омладински листови и наш нови нараштај из 1913. он пише: “Ми живимо у добу културног назатка, оживљавања мрског 'права песнице', када су човечански идеали, право и правда бачени под ноге, и када се у немилосрдном гажењу малих и слабих чује варварски крик: тешко малима, тешко побеђеним. Брутална сила једино има реч, и канцелари великих сила, када се ради о праву на живот малих народа, говоре језиком из доба када су тевтонски ритери 'мачем и огњем' истребљивали балтичка словенска племена."20

Књиге и чланци француских писаца биле су важан извор сазнања о феномену империјализма. У време Скерлићевог уредништва, Гласник је објавио превод огледа Ренеа Пинона о немачком и енглеском империјализму, у коме је посебно истакнут специфичан цивилизаторски жар, као особеност немачког

\footnotetext{
${ }^{16}$ Исти, Омладински Конгреси, Српски књижевни гласник (даље: СКГ), 1904, ХІІІ, св. 2, 126, 127.

${ }^{17}$ Исто, 124.

${ }^{18}$ Исто, 127.

${ }^{19}$ Исти, Начело солидарности, Исто, 1904, ХІ, св. 8, 592.

${ }^{20}$ Исти, Нови омладински листови и наш нови нараштај, Исто, 1913, ХХХ, св. 3, 221.
} 
империјализма. Пинон је тврдио да Немци носе у себи осећање цивилизацијске супериорности, удружено са спремношћу да се, у ширењу те цивилизације, послуже силом: “Немци налазе код својих филозофа ову идеју о Немачкој која влада силом и служи се њоме да васпостави један виши ступањ цивилизације, припремљене немачким генијем. Од Хегла до Ничеа читава једна поворка мислилаца засновала је метафизику о благотворној сили и о рату носиоцу реда и напретка. Ово су схватање, коме је Вагнер био псалмопевац а Бизмарк га приводио у дело, професори универзитета раширили све до најдубљих слојева народа. Батаљонима и оклопњачама немачким, трговином и поморством, треба да се рашири царство немачке науке и културе." 21

Српски интелектуалци из Гласника нису, наравно, имали лепих речи ни за британски и француски империјализам. Примећивали су, уосталом, да је било британских и француских писаца који су поздрављали „цивилизаторску мисију“ Аустријанаца у Босни и Херцеговини. Посебно је занимљив чланак Косте Куманудија у Гласнику из јула 1902, у коме се указивало на чињеницу да су Французи умели да упореде управу Двојне монархије у Босни и Херцеговини са својом влашћу над афричким и азијским колонијама. Кумануди је ту, наиме, приказао чланак о достигнућима Аустроугарске у Босни и Херцеговини, који је, у утицајном часопису Revue des Deux Mondes, гласилу либералних, прокатоличких париских кругова, објавио Анатол Лероа-Болије, ${ }^{22}$ један од водећих идеолога француског империјализма. ${ }^{23}$ у Калајевој управи над Босном и Херцеговином Лероа-Болије је, наиме, видео уношење западњачког реда и цивилизације међу инертне становнике истока. ${ }^{24}$ Он је чак, како преноси Кумануди, тврдио да би Босна и Херцеговина требало да буду узор из кога би и Француска могла да извуче поуке за своју колонијалну управу у Алжиру, Тунису и Индокини. ${ }^{25}$ Лероа-Болије је подржавао и језуите који су, за разлику од непоузданих локалних фрањеваца, у Босни и Херцеговини спроводили идеје папе Лава XIII и бискупа Штросмајера, о савезу између Рима и Словена, и о уједињењу римокатоличке и православне цркве. ${ }^{26}$

Знало се и да Енглезима није било страно поређење хабзбуршке управе над Босном и Херцеговином са њиховим колонијалним искуством у Египту. Јован Јовановић Пижон ће 1912. пренети читаоцима Гласника садржај једног чланка из лондонског листа Times, из кога се видело да је оваквих идеја било и у Бечу и у Лондону. Ту се, поред осталог, тврдило да је министар иностраних послова Аустроугарске, гроф Ерентал, приликом сусрета Едварда VII и Франца Јозефа I, уочи самог припајања Босне и Херцеговине Хабсбуршкој монархији 1908, стављао

\footnotetext{
${ }^{21}$ Рене Пинон, Енглеско-немачко супарништво (Са француског прев. М. Зебић), Исто, 1909, ХХІІІ, св. 10, 777-778.

${ }^{22}$ Коста Кумануди, Једно Мишљење о Босни и Хериеговини. L’Autriche-Hongrie en Bosnie-Herzégovine. Nationalités, religions, gouvernement, Revue des deux mondes, 15 mars 1902, Исто, VII, св. 6, 1102-1109.

${ }^{23}$ E. Said, нав. дело, 293.

${ }^{24}$ К. Кумануди, Једно Мииљење о Босни и Хериеговини, 1107-1109.

${ }^{25}$ Исто, 1108-1109.

${ }^{26}$ Исто, 1105-1106.
} 
на знање Енглезима да се, као нешто сасвим природно, очекује да и они припоје Египат својој империји. ${ }^{27}$

У Гласнику су се ипак, приликом писања о моћном суседу, пажљиво мериле речи; његова мисија била је управо у томе да он, као модеран, српски и западњачки часопис, упркос цензури, редовно стиже међу Србе на подручју Аустроугарске. За време криза у односима између две земље, страх од “културне најезде" ипак је избијао на површину. Коста Кумануди је тако, после претећег споразума Аустроугарске и Русије у Мирцштегу 1903. године, отворено назвао Аустроугарску претходницом пангерманизма у походу на Словене, ${ }^{28}$ и закључио: "Под својим добрим жељама и цивилизаторском глеђи, Аустро-Угарска од увек крије ненаситу халапљивост, сва њена политика носи у себи освајачке амбиције". ${ }^{29}$ Владимир Ћоровић је, после Анексионе кризе 1908-1909, приказујући путопис једног немачког официра о Мостару, писао да је овај одлучио да “замочи сабљу у мастило [курзив В. Ћоровића], и отпочне књижевну каријеру радовима из земаља, гдје има толико мунара и харема, из крајева нових, неисцрпених, страних оној наивној њемачкој публици, која, кад се спрема на једну аутомобилску вожњу преко Саве, носи чадоре, конзерве и оружје, као да се спрема негдје у Тибет, или у оне толико страшно описиване крајеве око извора Нила". ${ }^{30}$ Ироничним и горким тоном, Ћоровић је, у ствари, оптуживао немачку публику да на Босну и Херцеговину гледа као на обичну, ваневропску колонију.

\section{III}

Одбацивање културног, научног и књижевног туторства суседне империје било је уочљиво у Гласнику још од његових првих бројева. Тада, 1901, у време уредништва Богдана Поповића и на почетку опозиционе борбе Гласника против режима краља Александра Обреновића, ${ }^{31}$ требало је демонстративно показати своје мишљење и у питању односа Србије са Аустроугарском. У томе су предњачили они чланови Гласниковог Уређивачког одбора, који су долазили из Политичкопросветног одељења српског Министарства иностраних дела, задуженог за националну пропаганду у Старој Србији и Македонији. У прегледу дотадашње спољне политике кнежевине и краљевине Србије, Слободан Јовановић је поредио положај Србије према Аустроугарској, после “Тајне конвенције”, са односом Туниса према Француској, после колонијалног освајања из исте године. ${ }^{32} \mathrm{y}$ закључку, Јовановић је отворено писао да ће Србија морати да уђе у сукоб са

\footnotetext{
${ }^{27}$ Инострани, Гроф Ерентал. Избори у Турској, Исто, 1912, XXVIII, св. 5, 392.

${ }^{28}$ Коста Кумануди, Поглед на улогу Русије и Аустрије у Источном Питағу, Исто, 1903, Х, св. 8, 604.

${ }^{29}$ Исто, 605.

${ }^{30}$ Владимир Ћоровић, Mostar, von Robert Michel, Prag 1909, Исто, 1910, XXIV, св. 5, 390.

${ }^{31}$ Вид. Милош Ковић, Политичка улога “Српског књижевног гласника” 1901-1914, Сто година Српског књижевног гласника, 363-378; Слободан Јовановић, Политичко порекло С. К. Гласника, СКГ, 1931, XXXII, св. 2, 129-131; Исти, Светислав Симић, Исто, 1941, LXII, св. 6, 437-439; Исти, Оснивағе Српског књижевног гласника, Тамо далеко, год I, бр. 1, окт.-дец. 1958, 2-12; Исти, Влада Александра Обреновића II (1897-1903), Београд 1931, 267-270.

${ }^{32}$ Исти, Спољашња политика Србије у ХІХ веку, СКГ, 1901, IV, св. 6, 472.
} 
Аустроугарском. ${ }^{33}$ Светислав Симић и Љубомир Јовановић, међу Гласниковим сарадницима признати за стручњаке у пословима "националног рада", такође нису крили нерасположење према северном српском суседу. ${ }^{34}$ Љубомир Јовановић је, разматрајући дотадашњи “национално-политички живот српски”, тврдио да је, са почетком хабзбуршког продора ка југоистоку, на Берлинском конгресу, на место главног српског противника, уместо Турске, дошла Аустроугарска, и да ће "XX век моћи видети многу борбу између ње и српства". 35

Драгомир Јанковић је, као и Слободан Јовановић и Светислав Симић, имао значајно искуство у националној пропаганди. У прегледу стања у српском позоришту, који је у Гласнику објавио 1901, док је у МИД-у водио Политичкопросветно одељење, приметио је да на репертоарима преовлађују преводи са мађарског и немачког језика. "Ми тиме губимо и у културном и у националном погледу" - упозорава Јанковић. ${ }^{37}$ Он додаје да се у Србији чак и француски и енглески писци преводе са немачког, и предлаже да се, по француском узору, заштите национални писци и национална драма. ${ }^{38}$

За тему одбијања научног старатељства Аустроугарске од стране српских интелектуалаца, посебно је значајан био један текст Љубомира Стојановића, објављен у првој Гласниковој свесци из 1901. Његов приказ студије Милана Решетара Српско-хрватски нагласак у југозападним говорима у издању “Балканске комисије” Бечке академије наука, објављен је одмах иза Јанковићевог прегледа позоришних прилика. Стојановић је ту навео делове из једног саопштења “Балканске комисије", у коме је стајало да су историографско-археолошка и филолошко-етнографска истраживања Балкана "један од природних, Академије достојних и првих наших културних задатака" [курзив Љ. Стојановића]. "Из "Иаз 'сфера интереса' тако је постао омиљен у Аустрији, да га аустријски научењаци употребљавају и у науци кад се тиче - Балканског полуострва” - примећује Стојановић. ${ }^{40}$ Препознајући у томе намере које нису биле само научне природе, он додаје: "Не треба сметати с ума да су из Беча слате и да се шиљу научне експедиције и у друге стране света (на пр. у Индију, одакле су донели и мало куге у Беч), а научна сфера интереса није помињата, она је резервисана само за Балкан, ту не сме нико да дође сем њих." 41 У истом тону, поводом филолошких истраживања

\footnotetext{
${ }^{33}$ Исто, 472-473.

${ }^{34}$ Милош Ковић, Источно питање као културни проблем: Светислав Симић и “Српски књижевни гласник” 1901-1911, Европа и Источно питање (1878-1923): политичке и цивилизацијске промене (ур. Славенко Терзић), Српска академија наука и уметности, Београд 2001, 618-622.

35 Љубомир Јовановић, Преглед национално-политичког живота српскога у ХІХ веку, СКГ, 1901, III, св. 1, 49.

${ }^{36}$ Драгослав Јанковић, Поглед на данашње позоришне прилике, Исто, I, св. 1, 63-65.

${ }^{37}$ Исто, 67.

${ }^{38}$ Исто, 63, 65.

39 Љубомир Стојановић, Српско-хрватски нагласак у југо-западним говорима од Милана Решетара, Исто, 1901, I, св. 1, 70.

${ }^{40}$ Исто, 69.

${ }^{41}$ Исто, 70.
} 
бечких научника на Балкану, Стојановић закључује: “Свршили људи код куће испитивање свих многобројних језика, па неће да седе беспослени већ се кренули на Балкан."42

Љубомир Стојановић отворено је написао оно што је било на уму Гласникових оснивача: патронату немачке и аустроугарске науке требало је супротставити се подизањем квалитета националне продукције, уз угледање на француске и енглеске узоре. Неколико година раније, Љубомир Стојановић је већ био ступио у полемику са Ватрославом Јагићем, својим бившим бечким професором и водећим славистичким ауторитетом, пошто је, по Стојановићевом мишљењу, Јагић својим стручним радовима подржавао владину политику у Босни и Херцеговини, оличену у Бењамину Калају. ${ }^{43}$ У приказу Решетарове књиге Стојановић се, као бивши немачки ђак, није случајно потписао са: "У Паризу, јануара 1901, Љ. Стојановић". ${ }^{44}$ Он ће се, скоро тридесет година касније, у Гласниковој “новој серији”, сећати да је, уочи Великог рата, сам Франц Фердинанд волео да каже да “Балкан треба задобити за европску цивилизацију”. ${ }^{45}$

Овај програмски отпор успостављању "научне сфере интереса" Аустроугарске на Балкану, уз ослањање на француске и енглеске узоре, још јасније ће демонстрирати Михаило Гавриловић. У својој критици Историје српског устанка Бењамина Калаја, коју је приредио Калајев најближи сарадник, историчар Лајош Талоци, ${ }^{46}$ Гавриловић је указао на читав низ доказа ьихове методске неспремности. У Талоцијевом тексту он уочава "више мање дискретне лекције Србима и извесну висину када говори о њиховим стварима. Ми се на томе нећемо заустављати, тај је манир већ постао право и мађарских листова другога реда." ${ }^{, 4}$ Гавриловић се, као ђак француске историографске школе, уместо тога, зауставио на примерима Талоцијеве политичке пристрасности, чињеничних грешака, непознавања архивске грађе и литературе француског, руског и српског порекла. ${ }^{48}$ Талоци, како је тврдио Гавриловић, није добро познавао ни француски језик. ${ }^{49}$

Исти мотиви подстакли су још једног француског ђака, Богдана Поповића, да, као уредник Гласника, износи опште, негативне судове о дометима тадашње аустријске и немачке књижевности. ${ }^{50}$ Зато и Тихомир Ђорђевић, школован у Средњој Европи, као и Љуба Стојановић, када набраја “најкрасније градове” Европе,

\footnotetext{
${ }^{42}$ Исто.

${ }^{43}$ Исти, Приступна академска беседа Љуб. Стојановића говорена на свечаном скупу Академије 11. јан. 1896, Глас Српске краљевске академије, LII, 34, Београд 1896, 25-29; Исти, Јагић и Облак о приступној академској беседи, Дело, XIV, 1897, 347-362.

${ }^{44}$ Исти, Српско-хрватски нагласак у југо-западним говорима од Милана Решетара, 74.

${ }^{45}$ Исти, Хрватска “Аустријанштина”, Исто, 1926, XVII, св. 5, 360.

${ }^{46}$ Вид. Т. Kraljačić, нав. дело, 252-256, 267-272.

${ }^{47}$ Михаило Гавриловић, Историја српског устанка 1807-1810 од Бењамина Калаја, СКГ, 1910, XXV, св. 9-10, 788.

${ }^{48}$ Исто, 787-797.

${ }^{49}$ Исто, 794.

${ }^{50}$ Непотписано, Немачка сецесионистичка лирика, Исто, 1902, V, св. 5, 392; Исти, Пол Верлен у Немаца, Исто, 1902, VII, св. 6, 473; (У. Б.), Артур Шниилер, “Потпоручник Густел” (1901), Исто, V, св. 3, 237.
} 
не помиње Берлин или Беч, него Париз и Лондон, ${ }^{51}$ док француски ђак Милан Грол пише да у “београдском Народном позоришту није место ни аустријским валцерима ни капларским галантеријама". 52 Те идеје допиру свуда где стиже Гласник; Јован Скерлић је задовољно преносио захтеве омладине из Босне и Херцеговине за “признање логичне, француско енглеске интерпункције, којом се данас све више пише у Београду, у место немачке, граматичке интерпункције". ${ }^{53}$

Скерлић је, као и обично, био најотворенији. Од Омладинских конгреса из 1904, преко расправа са “пречанским" српским интелектуалцима, до полемике са Станојем Станојевићем из 1910. године, он је упорно потцењивао “аустријску полукултуру" и заговарао културну еманципацију Србије, уз угледање на западњачке узоре. Најјаснији је био у полемици са Станојевићем, када је лични сукоб претворио у начелну дебату између присталица француских и немачких културних и научних узора. Пошто је нагласио да је Станојевић “аустријски ђак” и да "он тврдо мисли да је Беч средиште светске културе и источник највише мудрости”, ${ }^{54}$ Скерлић примећује да је Станојевић сасвим лишен познавања “других култура, и то култура не равних аустријској култури но несравњено виших од ње.”,55 После неколико општих, потцењивачких опаски о интелектуалним моћима Немаца, ${ }^{56}$ Гласников уредник закључује: "Г. Станојевић зна само оно што су га у школи учили, мисли да сем немачке културе нема друге културе, и да је Беч Атина нашега доба. Он није у стању да схвати цео овај наш успешни покрет последњих двадесет година да се Србија отресе аустријске полукултуре, да не буде проста духовна провинција аустријска. Г. Станојевић, са својим уским и примитивним схватањима, не може да појми да се ми данас учимо на правим изворима наше књижевне науке, код оних који друге уче, код Француза и Енглеза, и да смо ми у нашој еманципацији од 'славистичкога' филолошкога празнословља и троме и несварене немачке учевности толико успели да се данас историја српске књижевности може модерно и европски учити и радити само у Београду, у Београду и нигде више!" 57

У жару расправе, Скерлић је овде отворено и јасно рекао оно што је на другим местима само наговештавао. У неколико реченица, ту су истакнути политички мотиви научне и књижевне мисије Српског књижевног гласника. Вреди, међутим, приметити и да је у Гласнику, тако, на колонијалне аргументе из Беча и Берлина, узвраћено истом мером, генералним оценама о читавим народима и о “вишим" и “нижим културама". Из свог времена није се могло изаћи.

Уочи Првог светског рата Слободан Јовановић ће, у ректорској беседи, заговарати претварање Београдског универзитета у не само српски него и

\footnotetext{
${ }^{51}$ Тихомир Ђорђевић, О етнологији, Исто, 1906, XVII, св. 7, 520.

${ }^{52}$ Милан Грол, Питање о оперети у Народном позоришту, Исто, 1904, ХI, св. 4, 302-310.

${ }^{53}$ Јован Скерлић, Нови омладински листови и наш нови нараштај, 216.

${ }^{54}$ Исти, Очена Г. Станоја Станојевића о “Српској књижевности у ХVIII веку, Исто, 1910, XXV, св. 7 , 546.

${ }^{55}$ Исто.

${ }^{56}$ Исто.

${ }^{57}$ Исто, 547.
} 
југословенски “научни центар", који ће заузети “прво место" у “научном испитивању целог Балкана". 58 Текстови о Београдском универзитету и ректорске беседе у Српском књижевном гласнику често су представљали праве националнополитичке програме. ${ }^{59}$ На Скерлићевој сахрани 1914, његове основне идеје понављао је Павле Поповић, у говору у име Универзитета, да би закључио: ”И у Берлину и Бечу умиру професори, али ђаци не плачу за њима.”60

Иза начелних, научних и идеолошких подела стајали су, као и обично, лични сукоби. Јован Скерлић и Павле Поповић седели су, у “српском семинару” београдског Филозофског факултета заједно са Станојем Станојевићем и Александром Белићем. ${ }^{61}$ Станојевићев отац Скерлићу је био венчани кум, а Белић му је био пријатељ из детињства. ${ }^{62}$ Увод у сукоб било је објављивање негативне оцене Станојевићеве Историје Босне и Хериеговине у Гласнику из 1909, коју је потписао Јован Томић, ${ }^{63}$ близак пријатељ Павла Поповића; у њиховој приватној преписци, из исте године, критичке опаске на рачун Станојевића и Белића нису биле ретке. ${ }^{64}$ Отворен сукоб избио је 1910. године, када је Станојевић, у Летопису Матице српске, објавио необично оштре критике Скерлићевих и Поповићевих научних радова. ${ }^{65}$ У одговорима, штампаним у Српском књижевном гласнику, ${ }^{66}$ Скерлић и Поповић тврдили су да су Станојевићеви мотиви били сасвим лични, и да је он покушавао да, по сваку цену, дође до места редовног професора на Универзитету, при чему је њих двојицу доживљавао као супарнике. ${ }^{67}$ После овог сукоба кроз “српски семинар” повучена је невидљива линија раздвајања: са једне стране били су Скерлић и Поповић, ђаци француских позитивиста, а са друге Станојевић и Белић, васпитаници аустријско-руске филолошко-критичке школе.

\footnotetext{
${ }^{58}$ Слободан Јовановић, Универзитетско питање, Исто, 1914, ХXXII, св. 3, 191-199.

${ }^{59}$ Вид. Петар Л. Вукићевић, Белешке о Универзитету, Исто, 1904, ХІІІ, св. 8, 599-601; Сава Урошевић, Пред Српским Университетом, Исто, 1905, ХІV, св. 3, 192-204; Исти, О Задатку Универзитета на просвећивању и моралном препорођају народа, Исто, 1909, ХХІІ, св. 3, 198-201; Исти, Наша Университетска Омладина, Исто, 1910, XXIV, св. 3, 184-198.

${ }^{60}$ Павле Поповић, Др Јован Скерлић, Исто, 1914, ХХХІІ, св. 10, 786.

61 Драгољуб Павловић, Димитрије Вученов, Катедра за историју југословенске къижевности, Сто година Филозофског факултета (ур. Радован Самарџић), Народна књига, Београд 1963, 358.

62 Живомир Младеновић, Универзитетска каријера и женидба, Живот и дело Јована Скерлића, Београд 1998, 81.

${ }^{63}$ Јован Томић, Ст. Станојевић, Историја Босне и Хериеговине. У Београду у Државној итампарији Краљевине Србије 1909, СКГ, 1909, ХХІІ, св. 10-11, 783-789, 846-855.

${ }^{64}$ Архив Српске академије наука и уметности (даље: АСАНУ), Јован Томић, заоставштина, Београд, 14509/V-93/9, П. Поповић - J. Томићу, Беч 10. 12. 1909; Исто, 14509/V-93/10, Беч 15. 1. 1910; Исто, 14509/V-93/12, Петроград На Св. Саву 1911.

${ }^{65}$ Станоје Станојевић, Стара српска књижевност у Прегледу српске књижевности г. Павла Поповића, Летопис Матице српске, 1910, св. 268, 50-61; Исти, Јован Скерлић, Српска књижевност у ХVIII веку, Исто, 61-69.

${ }^{66}$ Јован Скерлић, Оцена Г. Станоја Станојевића о “Српској Књижевности у ХVIII веку”, 1910, СКГ, XXV, св. 6-7, 457-473, 544-550; Павле Поповић, Станоје Станојевић, Критика на “Преглед српске книжевности”, Исто, св. 10-12, 767-787, 853-876, 929-955.

${ }^{67}$ Ј. Скерлић, Оиена Г. Станоја Станојевића о “Српској Книжевности у ХVIII веку”, 548-550; П. Поповић, Станоје Станојевић, Критика на “Преглед српске књижевности”, 767-768.
} 
Примери осталих европских “малих народа", који су се сукобљавали са немачким империјализмом, охрабривали су српске интелектуалце у отпору према “културној мисији” суседне царевине. Гласник је пажљиво пратио сукоб Масарикових Чеха са Немцима, и њихов, како су говорили, “културни приватан рад" ${ }^{68}$ На исти начин Гласник је тумачио чак и норвешко питање. У приказу извођења дела Едварда Грига у Народном позоришту, Цветко Манојловић је 1908. писао о намери норвешког композитора да ослободи норвешку музику од немачких утицаја. По њему, Григ је схватио да "Норвешка може да створи свој језик, своју слободу и потпуно независну уметност. Стога је у првом реду требало: 'Одвојити се од иностранства, одвојити се од Немачке'.,69

Још је занимљивија била белешка Павла Поповића о Бјернстјерне Бјернсону, у којој су на место “културних поробљивача" Немаца, постављени Данци, стари господари Норвешке. ${ }^{70}$ “Норвешки народ, политички слободан, полако се ослобађао од некадашњег интелектуалног утицаја Данске", ${ }^{71}$ али је у норвешкој књижевности још увек преовлађивао застарели дански романтизам. ${ }^{72}$ Тада се овај “усамљени артиста" који “носи у себи душу, аспирације и наде целе Норвешке,,73 ставио “на чело радикалне партије и покрета за интелектуалну еманципацију”, ослоњен на “модеран европски дух”, на дела Џона Стјуарта Мила, Иполита Тена и других западних писаца. ${ }^{74}$ Изговорити име Бјернстјерне Бјернсона значило је, по Поповићу, “завитлати норвешком заставом”. ${ }^{75}$

Оваква слика Бјернсона није значајније одударала од његове реалне улоге у норвешком културном и политичком животу. ${ }^{76}$ О њему је у Гласнику и касније доста писано. ${ }^{77}$ Тиме као да се хтело нагласити да је Бјернсон, конвенционални грађански

68 (И.Ш.) [Иван Шајковић], Slovanska kancelar (“Agence Slave”), Исто, 1902, V, св. 3, 239-240; Исти, Naše Doba, Исто, св. 4, 317-318; Исти, Zemedelska politika, Исто, 319; Исти, Прва раденичка изложба у Прагу, Исто, 320; Др. Иван Шајковић, Словенски клуб у Београду, Исто, св. 5, 343-348; Непотписано, С̆eska otazka, Исто, 391; Непотписано, ”Једноженство и многоженство” од Т. Г. Масарика, СКГ, 1902, VII, св. 6, 472; Јаша Продановић, О задацима Ђака. Од проф. Т. Г. Масарика. Превео Др Иван Шајковић 1902, СКГ, 1902, VII, св. 2, 233-235; Др Томаж Масарик, Етика и алкохолизам, Исто, 1909, ХХІІІ, св. 2, 122138.

${ }^{69}$ Х.Х.Х., Едвард Григ, Исто, 1908, ХХ, св. 1, 64.

${ }^{70}$ Непотписано, Бјернстерне Бјернсон, Исто, 1903, VIII, св. 1, 79-80.

${ }^{71}$ Исто, 80.

${ }^{72}$ Исто.

${ }^{73}$ Исто.

${ }^{74}$ Исто.

${ }^{75}$ Исто, 79.

${ }^{76}$ О Бјернсону и његовој политичкој улози вид. Ronald. G. Popperwell, Norway, London-Tonbridge, 1975, 240-242.

${ }_{77}$ Вид. опширан оглед Георга Брандеса, Бјернстјерне Бјернсон (с немачког прев. Никола Стајић), СКГ, 1909, ХХІІІ, св. 3, 4, 6, 7, 8, 9, 204-216, 288-297, 453-460, 532-544, 605-613, 694-700; вид. и: (Р.) [Павле Павловић], Бјернстјерне Бјернсон. “Laboremus”, Исто, 1901, III, св. 2, 156-158; Непотписано, Бјернстјерне Бјернсон, Исто, 1903, VIII, св. 1, 79-80; Л. [Бранко Лазаревић], Бјернстјерне Бјернсон, Исто, 
писац 19. века, бранилац права малих народа и капетана Драјфуса, ${ }^{78}$ Гласнику био много ближи него његов земљак, радикални индивидуалиста, побуњеник и модерниста Ибзен. Штавише, поводом Ибзенове смрти, писац читуље у Гласнику је чак приметио да је овог писца нарочито поштовала “германска штампа". ${ }^{79}$

$$
* * *
$$

Водећи интелектуалци у Краљевини Србији, окупљени, после 1901, око Српског књижевног гласника, били су, по свему судећи, веома свесни чињенице да су живели у «добу империја». Штавише, свој укупан јавни рад видели су као израз одбране српске културе од колонијалне, «цивилизаторске мисије» Аустроугарске. То је идеолошки оквир који је потребно имати на уму приликом сваке анализе не само спољне и унутрашње политике Краљевине Србије него, пре свега, њене културе, у одлучујућим годинама уочи Првог светског рата.

\section{Извори и литература:}

Извори:

Архив Српске академије наука и уметности (АСАНУ), Заоставштина Јована Томића

Српски књижевни гласник 1901-1941

Грол, Милан, Из предратне Србије: Утисии и сећања о времену и људима, Београд 1939. Јовановић, Слободан, Влада Александра Обреновића II (1897-1903), Београд 1931.

Јовановић, Слободан, Оснивање Српског књижевног гласника, Тамо далеко, год I, бр. 1, октдец. 1958, 2-12.

Скерлић, Јован, Фељтони, скище и говори, Сабрана дела Јована Скерлића VII, Београд 1964.

Станојевић, Станоје, Стара српска књижевност у Прегледу српске књижевности г. Павла Поповића; Јован Скерлић, Српска кьижевност у XVIII веку, Летопис Матице српске, 1910, св. 268, 50-69.

Стојановић, Љубомир, Јагић и Облак о приступној академској беседи, Дело, XIV, 1897, 347362

Стојановић, Љубомир, Приступна академска беседа Љуб. Стојановића говорена на свечаном скупу Академије 11. јан. 1896, Глас Српске краљевске академије, LII, 34, Београд 1896, 25-29.

\section{Литература:}

Витошевић, Драгиша, Српски књижевни гласник 1901 - 1914, Београд 1990.

Војводић, Михаило, Србија у међународним односима крајем ХІХ и почетком ХХ века, Београд 1988.

Ђорђевић, Љубица, Библиографија Српског књижевног гласника, Београд 1982.

1910, XXIV, св. 9, 718-720; Милан Грол, Банкротство, комад у четири чина, од Бјернстјерна Бјернсона, Исто, XXV, св. 8, 602-605.

${ }^{78}$ R. G. Popperwell, нав. дело, 242.

${ }^{79}$ Ив. [Милош Ивковић], Хенрик Ибзен, СКГ, 1906, XVI, св. 10, 799-800. 
Encyclopedia of the Age of Imperialism, 1800-1914, I-II (ed. by Carl Cavanagh Hodge), Westport London 2008.

Encyclopedia of Western Colonialism since 1450, I-III (ed. by Thomas Benjamin), Detroit - New York 2007.

Young, Robert J. C., Postcolonialism: A Very Short Introduction, Oxford - New York 2003.

Ковић, Милош, Источно питање као културни проблем: Светислав Симић и "Српски къижевни гласник” 1901-1911, Европа и Источно питање (1878-1923): политичке и цивилизацијске промене (ур. Славенко Терзић), Српска академија наука и уметности, Београд 2001, 595-628.

Kraljačić, Tomislav, Kalajev režim u Bosni i Hercegovini 1882-1903, Sarajevo 1987.

Младеновић, Живомир, Живот и дело Јована Скерлића, Београд 1998

Momsen, Wolfgang J., Theories of Imperialism, Chicago 1982

Okey, Robin, Taming Balkan Nationalism: The Habsburg 'Civilizing Mission' in Bosnia, 18781914, Oxford 2007.

Popperwell, Ronald. G., Norway, London - Tonbridge, 1975.

Porter, Andrew, European Imperialism 1860-1914, Houndmills -London 1994.

Renouvin, Pierre, Evropska kriza i Prvi svjetski rat, Zagreb 1965.

Said, Edvard, Orijentalizam, Beograd 2008.

Sked, Alan, The Decline and Fall of the Habsburg Empire 1815-1918, London - New York 1989.

Сто година Српског књижевног гласника, Аксиолошки аспект традиције у српској къижевној периодици (ур. Станиша Тутњевић и Марко Недић), Матица српска и Институт за проучавање књижевности и уметности, Београд 2003.

Сто година Филозофског факултета (ур. Радован Самарџић), Народна књига, Београд 1963.

Тејлор, Ален Џ. П., Хабсбурика монархија 1809-1918. Историја Аустријске иаревине и Аустроугарске, Београд 2001.

Todorova, Marija, Imaginarni Balkan, Beograd 2006.

Tomlinson, John, Cultural Imperialism: A Critical Introduction, London - New York 2002.

Hobsbawm, Eric, The Age of Empire 1875-1914, London 1987. 
MILOŠ KOVIĆ

\title{
THE AUSTRO-HUNGARIAN “CIVILIZING MISSION” IN THE BALKANS: A VIEW FROM BELGRADE (1901-1914)
}

\begin{abstract}
Summary
In this article the conflict between Serbia and Austria-Hungary on the First World War's eve is scrutinized within the context of the "Age of Empires". The main ideological tool of the Austria Hungary's colonial enterprize in the Balkan was its "civilizing mission" in the "semi-oriental", "barbarian" Balkan lands. The leading intelectuals of Serbia, mainly educated in the West, which were gathering around the "Serbian Literary Herald" magazine, were perfectly aware of these circumstances. Their articles in the "Herald" and other magazines and journals demonstrated different strategies of resistance to the colonial pressure of the neighbouring Empire. One of those strategies was the avoidance of cultural colonization through the westernization of Serbian culture, but according to French and British, and not the German or Austro-Hungarian patterns.
\end{abstract}

Keywords: empire, imperialism, “civilizing mission”, nationalism, AustriaHungary, Serbia, "Serbian Literary Herald" 